Círculo de Lingüística Aplicada a la Comunicación

ISSN: $1576-4737$

http://dx.doi.org/10.5209/CLAC.56329

\title{
Valencia 2017: 1st International Conference on Corpus Analysis in Academic Discourse
}

http://caad.upv.es

Cómo citar: Valencia 2017: 1st International Conference on Corpus Analysis in Academic Discourse. Círculo de Lingüística Aplicada a la Comunicación 70, 273. http://www.ucm.es/info/circulo/no70/valencia.pdf. http://dx.doi.org/10.5209/CLAC.56329

Applied Linguistics Department, Universtat Politècnica de València, 22-24 November 2017

3 July 2017: Deadline for submissions

20 July 2017: Notification of acceptance

This conference aims to provide language researchers with an opportunity to present and communicate their work from a variety of corpus analysis and academic discourse studies perspectives. For the 1st International Conference on Corpus Analysis in Academic Discourse, particular attention will be paid to corpus studies and academic discourse analysis (whether monolingual or multilingual). This conference is framed within the research project FFI2016-77941-P (Ministerio de Economía y Competitividad, Spain). The particular aim of CAAD'17 is thus to examine the means by which corpus linguistics attempts to detect and analyse different aspects of academic discourse, with the ultimate aim of achieving a better understanding of how they function in the language system. 